\title{
Assessment of selected parameters of biochemistry, hematology, immunology and production of pigs fattened in different seasons
}

\author{
Anna Chmielowiec-Korzeniowska', Leszek Tymczyna' and Marek Babicz² \\ 'Department of Animal Hygiene and Environment, ${ }^{2}$ Department of Pig Breeding and Production Technology, Faculty \\ of Biology and Animal Breeding, University of Life Sciences in Lublin, Lublin, Poland
}

\begin{abstract}
The present research objective was to asses the difference of some biochemical, hematological, immune and pork composition parameters in two groups of pigs fattened in winter and summer season. Pig performance was assessed in vivo (fattening and slaughter value) and post mortem studies which showed a season to be a significant factor influencing a level of some hematological and biochemical indices. In winter period, fatteners blood displayed increased leukocyte and immunoglobulin content with decreased red blood cell concentration. Whereas the animals finishing in the summer season had a higher growth rate. As compared to the winter period, the fatteners were found to have a higher content of crude protein, cholesterol and triglycerides as well as GGT, AST and cholinesterase concentration. In both seasons, the finishing pig carcasses had similar level of valuable cuts. A fattening season did not affect the technological value of the slaughter material obtained.
\end{abstract}

Keywords: fattener, fattening period, blood hematological index, blood biochemical index, slaughter value.

\section{Introduction}

Diseases of the respiratory system constitute one of the most challenging problems in pig production. Most frequently, the diseases are caused by infectious agents. It was also found that infection rate, disease prevalence and severity of clinical signs are dependent on animal management conditions, in that air quality and temperature at the fattening facility.

Nehme et al. (2008) highlight a significant correlation between air pollutants determined in a fattening house and the management period. Commonly applied practice of restricted air exchange in the pig facility in winter minimises temperature drops that keeps a feed consumption rate at a constant level as well as reduces disease incidence rate in the herd. Importantly, it causes increased air contaminant concentration.

The pollutants accumulate in the confined pig installations and can pose a direct health hazard to animals. There is evidence that airborne microorganisms, their products are capable of inducing immune responses and physiological changes in livestock (Grellner et al. 2002). The chemical compounds disturb the internal hormone and enzymatic balance leading to physiopathological changes as well as directly or indirectly compromised immunity (Dorman et al. 2002, Borell et al. 2007). The process of pig adaptation to definite environmental 
conditions induces a chain of metabolic and immune changes in animal organism, which contributes to differentiated productivity. In turn, this could result in a reduction in feed intake, as well as a diversion of protein and energy away from the development of muscle. Also growth performance of pigs and energy requirements depends on the ambient temperature. Energy demand is increasing dramatically during the cold season when the temperature decreases below the lower critical temperature (Lébret et al. 2002). In addition, the housing conditions are influenced meat quality, carcass composition, and quality of pork (Rosenvold \& Andersen 2003).

The present research objective was to asses the difference of some biochemical, haematological, immune and pork composition parameters in two groups of pigs fattened in winter and summer season.

\section{Material and methods}

Housing and management of the farm

The researches were carried out in the private farm specialised in pig production, average 105 Livestock Units. The study included two full fattening cycles conducted in the summer and winter period. The experiment commenced in January (winter period) and August (summer period) after the growing pigs of $25 \pm 2 \mathrm{~kg}$ body weight were introduced to the fattening facility. The studies lasted for the subsequent four months, until $112 \pm 4 \mathrm{~kg}$ body weight of pigs. The animals were managed in the straw-bedded deep litter which was removed once after each production cycle. Throughout the research period, the average animal number was 50 units/pen and stocking density $0.8 \mathrm{~m}^{2} /$ unit. The ventilation system in the finishing unit was based on the natural-mechanical ventilation with a thermal sensor. Fans automatically switched on when the indoor temperature raised up to $18^{\circ} \mathrm{C}$. At low temperatures, the air exchange was accomplished only by natural driving force.

Throughout the finishing period and before transport to the fattening facility, the animals were provided with routine prevention procedures and permanent veterinary care. Piglets aged 3 and 13 days received ferric preparations according to the prophylaxis programme. The 5-day old piglets underwent the needle teeth clipping and castration. The animals aged 2 weeks were vaccinated against $m$. hyopneumoniae followed by the disinfestations procedure.

The animals were given ad libitum access to balanced full ration feed in compliance with the production standards. The second feeding stage (finisher replaced grower) was introduced at late 17 week of age, i.e. when average animal body weight exceeded $70 \mathrm{~kg}$. At each pen, the animals had free access to two automatic feeders Tube-o-mat model equipped with two nipple drinkers (Egebjerg International A/S, Nykøbing Sj., Danmark). All the animals were free from stress susceptibility, with RYR1cc genotype identified by PCR-RLFP.

\section{Study design}

The effect of finishing season on fatteners health status was studied on the basis of haematological and biochemical parameters of pig blood (acceptance of the National Ethics Commission No 39/2006). Pig performance was evaluated on the grounds of in vivo 
examinations (fattening and slaughter value assessment) and post mortem. During both seasons, the microclimatic conditions in the fattening facility were monitored.

Assessment of pig health and productivity included healthy, free from any clinical manifestations barrows and gilts (1:1 sex ratio), F1 crossbreds of Polish Large White $\times$ Polish Landrace (PLW $\times \mathrm{PL}$ ). A total of 40 animals were studied, namely 20 units in the winter season and 20 units in the summer.

Blood for analyses was taken from random selected animals at 17 and 22 week of age, that is at the end of the first fattening stage (1st stage) and at the end of the second feeding stage (2nd stage). Blood was collected from the jugular vein into $4.9 \mathrm{ml}$ S-Monovette clot tubes (Sarstedt AG \& Co., Numbrecht, Germany) and into tubes containing K2-EDTA (Profilab Sc., Warsaw, Poland). At the same time (17 and 22 week) were assessed for fattening and slaughter of animals. Body weight measurement was taken in 11, 17 and 22 week of age.

The microclimatic parameters in the finishing unit were measured with the standard zootechnical methods. Air temperature and moisture readings were taken with a thermohygrometer (RT811E, Technik, Warsaw, Poland), air motion with anemometer (A-1200M1, OBRAiUP, Lodz, Poland) and cooling effect with catathermometer. Ammonia, hydrogen sulphide, carbon dioxide were measured using a QRAE Plus model PGM-2000 multi-gas monitor (RAE Systems, San Jose, USA). A dust level in the air was measured with a gravimetric method, the air samples were drawn via an aspirator (224-PCEX8, SKC, Dorset, England).

The haematological analyses were performed using haematology analyser Melet Schloesing Laboratories (Osny, France) to determine the following parameters: a level of haemoglobin (HGB) and haematocrit (HCT), red blood cell count (RBC), mean corpuscular volume $(\mathrm{MCV})$, mean corpuscular haemoglobin $(\mathrm{MCH})$, mean corpuscular haemoglobin concentration $(\mathrm{MCHC})$, red blood cell distribution width (RDW), platelet count (PLT), mean platelet volume (MPV), platelet distribution width (PDW), white blood cell count (WBC) and white blood cell parameters, in that the counts of lymphocytes (Lym), monocytes (Mon), neutrophils (Neu), eosinophils (Eos) and basophils (Baso).

In the fresh serum from centrifuged blood ( $15 \mathrm{~min} 3000 \mathrm{r} / \mathrm{min})$ using the analyser VITROS 5,1 FS (Ortho Clinical Diagnostics, Johnson \& Johnson Company, USA), there was established a content of crude protein, creatinine, urea, uric acid, total bilirubin, cholesterol, triglycerides, glucose and enzymatic profile indices, that is lactate dehydrogenase (LDH), gamma-glutamyltransferase (GGT), creatine kinase (CK), asparagine aminotransferase (AST) and alanine (ALT), cholinesterase. The single radial immunodiffusion assay VMRD, Inc. was applied to establish the immunoglobulin complex level including the following classes: IgA, $\lg M, \lg G$.

The evaluation of fattening and slaughter value was performed on the live animals using a Piglog 105 ultrasonic scanner (Carometec A/S, Germany). A percentage meat content was estimated on the grounds of depth of backfat and $m$. longissimus dorsi. The evaluation was made on the right side of animal body at two measurement points: $P_{2}$ backfat - behind the last rib, $3 \mathrm{~cm}$ from the midline; $\mathrm{P}_{4}$ thickness of backfat and $m$. longissimus dorsi - behind the last rib, $8 \mathrm{~cm}$ from the midline $\left(\mathrm{P}_{4} \mathrm{M}\right)$. The measurements served the basis for determination of a percentage of meat content in carcass. On the basis of body weight measurements were calculated average daily gains of finishing pigs in 1st and 2nd stage. 
The fatteners were slaughtered at $112 \pm 4 \mathrm{~kg}$ body weight in the meat processing plant. To measure the concentration of hydrogen ions 45 min after the slaughter $\left(\mathrm{pH}_{2}\right)$, the PH-STAR CPU device was applied. After $24 \mathrm{~h}$ chilling, the measurement was repeated $\left(\mathrm{pH}_{2}\right)$ and the carcasses were fabricated into wholesale cuts in accordance to the Polish standard PN86-A-82002 with valuable cut weight established.

To evaluate meat quality, the porcine right halfcarcasses were cut to collect standardised $m$. longissimus dorsi samples and those from ham $-m$. adductor femoris. There was determined a percentage of loose water, meat colour, basic chemical composition, i.e. dry matter, protein, fat and ash. A dry matter content was analysed with the dryer method, while, total crude nitrogen was established with the Kjeldahl method. The nitrogen amount derived from the analysis was converted into protein content using the factor 6.25. A fat content was determined with Soxhlet method and ash level in compliance with the Polish standard PN-ISO 936:2000.

\section{Statistical methods}

The obtained results were analysed statistically and characterised with arithmetical mean and standard using Statistica 8.0 (StatSoft, Inc. Tulsa, OK, USA). Significance of differences for the fattening seasons and defined traits was verified with ANOVA. A level of significance of differences was analysed in relation to $P<0.05$ and $P<0.01$ (Tukey's test).

\section{Results}

As compared to the summer fattening period, in the first stage of the winter period there was determined a lower (by average $12.8^{\circ} \mathrm{C}$ ) temperature but higher (by average 19.9\%) relative moisture content, elevated air motion (by average $0.1 \mathrm{~m} / \mathrm{s}$ ) and cooling rate (by average $1.4 \mathrm{~W} / \mathrm{dm}^{2}$ ) (Table 1). Out of the contaminants established in the fattening facility air, in this season there was noted higher concentration of hydrogen sulphide (average by $4.4 \mu \mathrm{g} / \mathrm{m}^{3}$ ), ammonia (average by $4.3 \mathrm{mg} / \mathrm{m}^{3}$ ) but a lower level of total dust (average by $4.2 \mathrm{ug} / \mathrm{m}^{3}$ ). The differences were statistically insignificant $(P>0.05)$.

Table 1

Temperature of atmospheric air and the microclimatic parameters in fattening pigs during the winter and summer

\begin{tabular}{|c|c|c|c|c|c|c|c|c|}
\hline \multirow[t]{3}{*}{ Parameter } & \multicolumn{4}{|c|}{ Winter season } & \multicolumn{4}{|c|}{ Summer season } \\
\hline & \multicolumn{2}{|c|}{ 1st stage } & \multicolumn{2}{|c|}{ 2nd stage } & \multicolumn{2}{|c|}{ 1st stage } & \multicolumn{2}{|c|}{ 2nd stage } \\
\hline & mean & SD & mean & SD & mean & SD & mean & SD \\
\hline \multirow[t]{2}{*}{ Temperature of atmospheric air, ${ }^{\circ} \mathrm{C}$} & 3.2 & 2.0 & 15.8 & 5.1 & 26.4 & 4.2 & 16.1 & 5.1 \\
\hline & \multicolumn{8}{|c|}{ Microclimatic parameters in the finishing unit } \\
\hline Temperature, ${ }^{\circ} \mathrm{C}$ & 12.5 & 6.9 & 17.5 & 4.5 & 25.3 & 4.1 & 17.9 & 2.9 \\
\hline Moisture, \% & 75.5 & 9.2 & 66.0 & 4.8 & 55.6 & 14.0 & 83.5 & 3.5 \\
\hline Air motion, $\mathrm{m} / \mathrm{s}$ & 0.2 & 0.1 & 0.3 & 0.1 & 0.1 & 0.0 & 0.1 & 0.1 \\
\hline Cooling, W/dm² & 3.0 & 0.2 & 2.6 & 0.6 & 1.6 & 0.2 & 2.8 & 0.4 \\
\hline Ammonia, $\mathrm{mg} / \mathrm{m}^{3}$ & 22.7 & 3.4 & 17.4 & 5.4 & 18.4 & 1.0 & 20.3 & 4.3 \\
\hline Hydrogen sulphide, $\mu \mathrm{g} / \mathrm{m}^{3}$ & 10.4 & 3.3 & 8.9 & 2.9 & 6.0 & 7.6 & 16.8 & 2.8 \\
\hline $\mathrm{CO}_{2}, \%$ & 0.2 & 0.0 & 0.1 & 0.1 & 0.1 & 0.0 & 0.1 & 0.1 \\
\hline Dust, $\mathrm{mg} / \mathrm{m}^{3}$ & 0.8 & 3.0 & 5.3 & 2.7 & 5.0 & 2.1 & 6.8 & 2.8 \\
\hline
\end{tabular}


Comparison of the winter season to the first stage of summer fattening showed higher concentration of $\mathrm{HGB}, \mathrm{MCH}, \mathrm{MCHC}(P<0.01)$ as well as $\mathrm{HCT}$ and $\mathrm{RBC}(P<0.05)$ (Table 2). Bringing together both periods, higher MPV value was determined in fatteners blood $(P<0.01)$ as well as PDW $(P<0.05)$. The early winter fattening season was marked with significantly higher, as against the summer finishing time, concentration of leukocytes (average by $5.93 \times 10^{9} / \mathrm{l}$ ). Alike, significant differences were observed comparing the second finishing stage in summer. At this period, the blood of fatteners from the winter season showed a higher HCT and MCV $(P<0.05)$ level.

Table 2

Mean values of haematological parameters in fattening pigs in depending on season

\begin{tabular}{|c|c|c|c|c|c|c|c|c|}
\hline \multirow[t]{3}{*}{ Parameter } & \multicolumn{4}{|c|}{ Winter season } & \multicolumn{4}{|c|}{ Summer season } \\
\hline & \multicolumn{2}{|c|}{ 1st stage } & \multicolumn{2}{|c|}{ 2nd stage } & \multicolumn{2}{|c|}{ 1st stage } & \multicolumn{2}{|c|}{ 2nd stage } \\
\hline & mean & SD & mean & SD & mean & SD & mean & SD \\
\hline $\mathrm{HGB}, \mathrm{mmol} / \mathrm{l}$ & $6.92^{A}$ & 0.77 & 7.48 & 0.46 & $8.52^{\mathrm{AB}}$ & 0.61 & $7.92^{\mathrm{B}}$ & 0.45 \\
\hline $\mathrm{HCT}, \mathrm{I} / \mathrm{I}$ & $0.37^{\mathrm{Aa}}$ & 0.04 & $0.45^{\mathrm{Ab}}$ & 0.03 & $0.40^{\mathrm{a}}$ & 0.03 & $0.39^{b}$ & 0.05 \\
\hline $\mathrm{RBC}, 10^{12} / \mathrm{I}$ & $7.05^{\mathrm{ab}}$ & 0.58 & $7.85^{\mathrm{a}}$ & 0.59 & $7.61^{\mathrm{b}}$ & 0.47 & 7.59 & 1.00 \\
\hline $\mathrm{MCV}, \mathrm{fl}$ & $51.88^{a}$ & 3.47 & $56.93^{\mathrm{ab}}$ & 2.63 & 52.55 & 3.82 & $52.41^{b}$ & 4.01 \\
\hline $\mathrm{MCH}, \mathrm{fmol}$ & $0.98^{A}$ & 0.05 & 0.95 & 0.06 & $1.12^{\mathrm{A}}$ & 0.08 & 1.06 & 0.20 \\
\hline $\mathrm{MCHC}, \mathrm{mmol} / \mathrm{l}$ & $18.60^{A B}$ & 1.32 & $16.75^{A}$ & 0.46 & $21.35^{\mathrm{B}}$ & 0.72 & 35.38 & 52.49 \\
\hline RDW & 13.29 & 1.04 & 13.33 & 0.99 & 13.68 & 1.16 & 14.28 & 1.65 \\
\hline PLT, $10^{9} / \mathrm{I}$ & 270.33 & 67.28 & 362.50 & 93.93 & 322.71 & 91.70 & 346.00 & 135.45 \\
\hline MPV, fl & $9.63^{A B}$ & 0.23 & $10.20^{\mathrm{A}}$ & 0.25 & $10.06^{\mathrm{B}}$ & 0.31 & 10.18 & 0.42 \\
\hline PDW & $8.00^{\mathrm{a}}$ & 0.70 & 8.65 & 1.47 & 8.81a & 1.03 & 8.90 & 1.04 \\
\hline WBC, $10^{9} / I$ & $22.30^{A}$ & 3.92 & 20.30 & 2.27 & $16.37^{\mathrm{AB}}$ & 4.16 & $21.97^{B}$ & 4.52 \\
\hline Lim, \% & 53.82 & 11.98 & 56.65 & 4.66 & $52.51^{\mathrm{A}}$ & 8.38 & $62.04^{\mathrm{A}}$ & 7.56 \\
\hline Mon, \% & $5.08^{A}$ & 0.99 & $3.17^{\mathrm{A}}$ & 0.56 & $4.59^{\mathrm{B}}$ & 0.63 & $3.65^{B}$ & 0.59 \\
\hline Neu, \% & 37.78 & 13.19 & 36.12 & 4.76 & $38.72^{\mathrm{a}}$ & 7.95 & $31.27^{\mathrm{a}}$ & 7.05 \\
\hline Eos, \% & 2.98 & 1.02 & 2.68 & 1.00 & $3.73^{a}$ & 1.19 & $2.78^{a}$ & 0.98 \\
\hline Bas, \% & 0.35 & 0.24 & 0.38 & 0.31 & $0.46^{\mathrm{a}}$ & 0.28 & $0.27^{\mathrm{a}}$ & 0.17 \\
\hline
\end{tabular}

Means values marked with the same letters are statistically significantly different capital letters at $P \leq 0.01$, small letters at $P \leq 0.05$.

The statistical analysis displayed significant influence of a fattening stage on the haematological parameters under investigation. Comparing the results determined in 1st and 2nd stage of the winter fattening season, there was found the increase of red blood cell counts, in that HCT and MCHC $(P<0.01)$ and RBC and MCV $(P<0.05)$. Besides, the MPV growth was noted in this period. As far as white blood cell numbers, only monocyte counts appeared to be statistically significant $(P<0.01)$. In the late stage of the winter fattening, the finish pigs blood showed the raised leukocyte numbers with concomitant change in the white cell blood composition.

The analysis performed indicated substantial fluctuations of the indices of both, protein metabolism and enzymatic profile (Table 3). In the blood serum of fatteners at the summer period, significantly higher concentration of crude protein $(P<0.05)$, cholesterol and triglycerides $(P<0.01)$ was established. In the first weeks of the summer fattening, a level GGT, AST and cholinesterase $(P<0.01)$ was reported to be at a far higher level than at this time in the winter period. This tendency held true in the second stage of the summer fattening period. 
Table 3

Mean values of biochemical and immunological parameters in blood plasma pigs in depending on season

\begin{tabular}{|c|c|c|c|c|c|c|c|c|}
\hline \multirow[t]{3}{*}{ Parameter } & \multicolumn{4}{|c|}{ Winter season } & \multicolumn{4}{|c|}{ Summer season } \\
\hline & \multicolumn{2}{|c|}{ 1st stage } & \multicolumn{2}{|c|}{ 2nd stage } & \multicolumn{2}{|c|}{ 1st stage } & \multicolumn{2}{|c|}{ 2nd stage } \\
\hline & mean & SD & mean & SD & mean & SD & mean & SD \\
\hline Crude protein, g/l & $66.75^{\mathrm{ab}}$ & 4.49 & $75.80^{\mathrm{a}}$ & 7.40 & $70.50^{\mathrm{Ab}}$ & 3.76 & $76.75^{\mathrm{A}}$ & 5.40 \\
\hline Creatinine, $\mu \mathrm{mol} / \mathrm{l}$ & 148.81 & 23.79 & 152.05 & 22.01 & 145.86 & 16.17 & 170.91 & 52.82 \\
\hline Urea, mmol/l & $4.21^{\mathrm{a}}$ & 0.49 & $4.98^{\mathrm{a}}$ & 0.44 & 4.19 & 0.76 & 4.76 & 2.45 \\
\hline Uric acid, mmol/l & 0.03 & 0.01 & 0.03 & 0.00 & 0.03 & 0.00 & 0.03 & 0.00 \\
\hline Total bilirubin, $\mu \mathrm{mol} / \mathrm{l}$ & 1.71 & 0.00 & 1.71 & 0.00 & 1.71 & 0.00 & 1.71 & 0.00 \\
\hline Cholesterol, mmol// & $2.37^{\mathrm{aA}}$ & 0.35 & $2.84^{\mathrm{a}}$ & 0.36 & $2.78^{A}$ & 0.37 & 2.82 & 0.24 \\
\hline Triglycerides, mmol// & $0.33^{\mathrm{A}}$ & 0.13 & $0.49^{\mathrm{a}}$ & 0.15 & $0.80^{A}$ & 0.25 & $0.79^{\mathrm{a}}$ & 0.32 \\
\hline Glucose, $\mathrm{mmol} / /$ & $4.53^{\mathrm{A}}$ & 0.47 & $3.63^{\mathrm{AB}}$ & 0.49 & 4.74 & 0.33 & $4.54^{\mathrm{B}}$ & 0.50 \\
\hline $\mathrm{LDH}, \mathrm{U} / \mathrm{I}$ & 2106.25 & 292.29 & 1706.60 & 293.64 & $2178.64^{a}$ & 427.65 & $1831.08^{\mathrm{a}}$ & 376.98 \\
\hline GGT, U/I & $44.50^{\mathrm{aA}}$ & 9.68 & $75.20^{\mathrm{a}}$ & 18.02 & $63.86^{\mathrm{bA}}$ & 14.80 & $79.58^{b}$ & 16.85 \\
\hline CK, U/I & $498.67^{\mathrm{aA}}$ & 268.31 & $730.80^{\mathrm{a}}$ & 117.56 & $1888.86^{A}$ & 1342.44 & 1544.25 & 1664.42 \\
\hline AST, U/I & $50.50^{A}$ & 10.96 & 48.80 & 18.87 & $63.71^{\mathrm{A}}$ & 15.80 & 63.08 & 34.72 \\
\hline ALT, U/I & 72.50 & 20.63 & 61.80 & 8.61 & 65.93 & 10.51 & 62.17 & 12.60 \\
\hline Cholinesterase, $\mathrm{U} / \mathrm{ml}$ & $0.89^{\mathrm{aA}}$ & 0.14 & $0.78^{\mathrm{aB}}$ & 0.04 & $0.59^{\mathrm{A}}$ & 0.12 & $0.59^{\mathrm{B}}$ & 0.09 \\
\hline $\lg A, g / \operatorname{l}$ & $0.66^{\mathrm{A}}$ & 0.16 & $0.79^{\mathrm{B}}$ & 0.15 & $0.40^{\mathrm{A}}$ & 0.00 & $0.34^{\mathrm{B}}$ & 0.11 \\
\hline $\lg G, g / l$ & 14.51 & 2.58 & $14.28^{A}$ & 1.99 & $14.12^{\mathrm{B}}$ & 1.51 & $7.42^{\mathrm{AB}}$ & 1.02 \\
\hline $\lg M, g / l$ & $1.68^{\mathrm{a}}$ & 0.24 & $2.08^{\mathrm{aA}}$ & 0.33 & $1.94^{\mathrm{b}}$ & 0.41 & $1.28^{\mathrm{Ab}}$ & 0.44 \\
\hline
\end{tabular}

Means values marked with the same letters are statistically significantly different capital letters at $P \leq 0.01$, small letters at $P \leq 0.05$.

The late summer fattening season was marked with a higher content of triglycerides $(P<0.5)$, cholinesterase and glucose $(P<0.01)$.

In blood serum of pigs finished in the winter season, higher immunoglobulin concentration was detected. A level of antibodies determined proved to be influences by a season and fattening stage.

Table 4

Results of judging live in depending on season

\begin{tabular}{lrrrrrrrr}
\hline Parametr & \multicolumn{3}{c}{ Winter season } & \multicolumn{3}{c}{ Summer season } \\
& \multicolumn{2}{c}{ 1st stage } & \multicolumn{2}{c}{ 2nd stage } & \multicolumn{2}{c}{ 1st stage } & \multicolumn{2}{c}{ 2nd stage } \\
& mean & \multicolumn{1}{c}{ SD } & mean & \multicolumn{1}{c}{ SD } & mean & SD & mean & SD \\
\hline Body weight, $\mathrm{kg}$ & $70.87^{\mathrm{A}}$ & 11.43 & $101.80^{\mathrm{A}}$ & 10.44 & $70.00^{\mathrm{B}}$ & 4.93 & $98.50^{\mathrm{B}}$ & 6.19 \\
Backfat thickness $\left(\mathrm{P}_{2}\right), \mathrm{mm}$ & 11.27 & 2.22 & 11.60 & 2.17 & 12.00 & 1.62 & 12.75 & 2.96 \\
Loin »eye« height $\left(\mathrm{P}_{4} \mathrm{M}\right), \mathrm{mm}$ & 43.87 & 4.52 & $47.20^{\mathrm{a}}$ & 4.21 & $44.64^{\mathrm{A}}$ & 3.46 & $51.75^{\mathrm{Aa}}$ & 5.83 \\
Backfat thickness $\left(\mathrm{P}_{4}\right), \mathrm{mm}$ & 11.60 & 1.59 & 13.50 & 2.59 & 12.09 & 2.61 & 12.83 & 2.92 \\
Lean meat percentage, \% & 57.57 & 2.29 & 56.23 & 3.40 & 56.3957 .04 & 2.88 & 56.61 & 3.77 \\
Daily gain, g & 884.17 & 130.63 & 892.86 & 153.38 & 1175.8 & 492.17 & 919.44 & 132.16 \\
\hline
\end{tabular}

Means values marked with the same letters are statistically significantly different capital letters at $P \leq 0.01$, small letters at $P \leq 0.05$.

Throughout the research period, the finishing pigs underwent the live evaluation of fattening twice (Table 4). Statistical differences were noted in backfat thickness $\left(P_{2}\right)$ and height of loin eye $\left(\mathrm{P}_{4} \mathrm{M}\right)$. The fatteners in the second stage of the winter fattening had lower backfat thickness and the height of loin eye as compared to the levels established in the summer 
season. Daily body weight gains of pigs finishing in the winter season were lower as against those at the summer period by average $291.63 \mathrm{~g}$ in 1 st stage and $26.58 \mathrm{~g}$ in the $2 \mathrm{nd}$ one. The differences were not significant statistically.

The halfcarcasses of fatteners slaughtered in both seasons were characterised by a similar content of valuable cuts (Table 5). As compared to the summer period, in the winter fattening a significantly lower loin content was noted $(P<0.01)$.

The physical and chemical properties of ham and loin from the fatteners in both fattening periods did not show any statistically confirmed differences (Table 6).

Table 5

Weight of carcass cuts in depending on season

\begin{tabular}{lcccc}
\hline Parameter & \multicolumn{2}{c}{ Winter season } & \multicolumn{2}{c}{ Summer season } \\
& mean & SD & mean & SD \\
\hline Body weight, kg & 114.8 & 7.0 & 110.2 & 6.3 \\
Dressing percentage, \% & 79.8 & 3.8 & 78.5 & 2.4 \\
Ham, kg & 8.0 & 0.6 & 8.0 & 0.7 \\
Shoulder, kg & 4.8 & 0.6 & 4.5 & 0.3 \\
Loin, kg & $2.6 \mathrm{~A}$ & 0.2 & $3.0 \mathrm{~A}$ & 0.5 \\
Neck, kg & 1.8 & 0.2 & 1.7 & 0.2 \\
Bacon, kg & 3.3 & 0.6 & 3.2 & 0.6 \\
Ribs, kg & 2.7 & 0.3 & 2.6 & 0.3 \\
\hline
\end{tabular}

Means values marked with the same letters are statistically significantly different capital letters at $P \leq 0.01$, small letters at $P \leq 0.05$.

Table 6

Physical and chemical properties of ham and loin in depending on season

\begin{tabular}{lrrrrrrrr}
\hline Parameter & \multicolumn{3}{c}{ Winter season } & \multicolumn{5}{c}{ Summer season } \\
& \multicolumn{3}{c}{ Ham } & \multicolumn{2}{c}{ Loin } & \multicolumn{4}{c}{ Ham } & \multicolumn{2}{c}{ Loin } \\
& mean & \multicolumn{1}{c}{ SD } & mean & \multicolumn{1}{c}{ SD } & mean & SD & mean & SD \\
\hline $\mathrm{pH}_{1}$ & 6.07 & 0.48 & 6.10 & 0.41 & 6.23 & 0.41 & 6.10 & 0.31 \\
$\mathrm{pH}_{2}$ & 5.63 & 0.32 & 5.51 & 0.29 & 5.60 & 0.29 & 5.63 & 0.31 \\
Reemission (White), \% & 19.83 & 1.22 & 22.12 & 1.42 & 20.12 & 1.21 & 22.72 & 1.94 \\
\% of free water, \% & 24.11 & 1.34 & 26.94 & 1.81 & 22.83 & 1.72 & 25.34 & 1.42 \\
Chemical composition & & & & & & & & \\
$\quad$ Dry weight,\% & 24.06 & 0.51 & 25.24 & 1.06 & 23.87 & 0.72 & 26.27 & 0.17 \\
Total protein,\% & 21.00 & 0.07 & 22.06 & 0.05 & 21.16 & 0.64 & 21.98 & 0.30 \\
Fat,\% & 1.17 & 0.13 & 1.94 & 0.95 & 1.34 & 0.16 & 2.69 & 0.22 \\
Ash,\% & 1.26 & 0.08 & 1.17 & 0.04 & 1.10 & 0.03 & 1.09 & 0.03 \\
\hline
\end{tabular}

\section{Discussion}

The control of the thermal-moisture conditions in the fattening house showed that in both seasons the average air temperature in the first fattening weeks was beyond the optimal temperature range set for this animal species. The summer finishing period commenced in the month of high ambient air temperatures, while the average indoor temperature in the fattening unit surpassed $25^{\circ} \mathrm{C}$. Whereas in the winter season, a low temperature, elevated relative moisture and air motion contributed to a growing cooling rate. This air cooling rate during the first fattening weeks was so high that it may have affected negatively the animal 
health status. It is noteworthy that at the determination time, no negative air temperature values were noted, which are characteristic of the Eastern Europe climate.

Low air temperature in the winter season activated the excessive immune response which is associated with the marked increase of white blood cell counts and immunoglobulin numbers in blood. At that time, average leukocyte load exceeded the reference range values (Winnicka 2008) and indicated the ongoing immune response in the studied pigs (IsraëlAssayag \& Cormier 2002). Only at high air temperature period, i.e. the first stage of the summer fattening season, the numbers of leukocytes reached $16.37 \times 10^{9} /$ I and thus were within the reference limits. At the summer period, the deteriorating conditions at the finishing house at the late fattening season induced the raising leukocyte count with a concomitant change in white blood cell profile.

The studies of Frank et al. (2003) concluded that housing pigs below the recommended indoor temperature values favours the growth of inflammatory conditions, in those bacterial infections of the respiratory system. Interaction between cold temperature and air pollution in the pig house enhances stress reactions. In the winter period, that is the time of restricted air exchange, animal exposure to aerial pollutants with elevated ammonia concentration made the additional factor that burdened the finishing pigs immunity system. Such a high air ammonia content may irritate mucous membranes and respiratory tract causing physiological and immune disturbances as well as enhancing the incidence of the respiratory system diseases (von Borell et al. 2007). Generally, both clinical and subclinical forms of these diseases usually reduce feed conversion and animal growth rate but may also increase mortality rate in a swine herd (Oliveira et al. 2009).

Strong arousal of the immune system during the low temperature period in the fattening unit was reflected in elevated immunoglobulin concentration. Throughout the whole finishing season, blood serum of the fatteners showed high concentration of immunoglobulins class. A that plays a vital role in specific humoral immunity, in particular in bacterial conditions (Wines \& Hogarth 2006). Increased antibody class M titres in the second stage provided the evidence that during the fattening season the animals were exposed to a repeated contact with new pathogens. In addition, the red blood cell picture of these animals also showed some changes, including the decline of haematocrit value and haemoglobin concentration being characteristic of an inflammatory response (Odink et al. 1990). At the time of low temperature period there was also established lower red blood cell concentration (RBC) as well as MCH, MCHC level. Importantly, decreasing air pollution caused the rise of the red blood cell parameters.

The analysis performed displayed considerable fluctuations of the parameters of protein metabolism and enzymatic profile. In the blood serum of pigs fattened in the summer season there was found a significantly higher level of crude protein, cholesterol and triglycerides as well as gamma-glutamyltransferase (GGT), creatine kinase (CK) and asparagine aminotransferase (AST). These parameters were affected by the enhanced activity of metabolic changes as demonstrated by high growth rate of the pigs under study (Verheyen et al. 2007). Daily weight gains of the pigs finished in the summer season were higher as compared to those from the winter period by average $291.63 \mathrm{~g}$ at the fattening start and by $26.58 \mathrm{~g}$ at its completion. Although the differences were insignificant statistically, the analyses showed that the cold stress is likely to reduce the 
productivity and prolong the fattening season. The effect of piggery temperature on daily weight gains was studied by Sakai et al. (1992). Authors demonstrated that weaning rate and fattening completion rates were similar among piglets born in different seasons of the year but the average daily weight gain was slower during the early (20 to $40 \mathrm{~kg}$ live weight) and intermediate (40 to $60 \mathrm{~kg}$ live weight) periods of fattening in the autumn-born group whilst during the late period (60 to $80 \mathrm{~kg}$ live weight) slower growth rates were found in the summer- and winter-born groups.

The present research demonstrated that a fatting season did not affect the technological value of the slaughter material. Technological quality of meat was expressed by basic chemical composition of meat and some physical parameters. In this respect, the samples of muscle tissue of ham and loin showed good quality and the obtained values were found within the limits of the quality class of normal meat. The finishing pigs from the 2 nd stage of winter fattening season had less backfat and smaller loin eye area as compared to the parameters recorded in the summer season. It was directly reflected in the carcass meatiness score. Average percentage of meat content in the finish pigs at 1st and 2nd fattening stage proved to be lower than in the fattening season that commenced under high ambient air temperatures.

Other study showed that the ambient temperature could affect carcass composition and muscle properties. Lefaucheur et al. (1991) noted that the environmental temperature dramatically changed some of the muscle and adipose tissue characteristics. The effect of muscle protein loss is known not only to lessen the production performance but to lower the slaughter value of carcasses as well. Cold-acclimated pigs had lower $\mathrm{pH}_{1}$ in muscle than pigs kept in warm environment, the latter begin in the usual range of $\mathrm{pH}$ values measured in pigs of the same breed and herd slaughtered in the same place. Cold exposure enhanced the glycolytic capacity of the $m$. longissimus and led to lower initial and ultimate post mortem $\mathrm{pH}$, thus decreasing the technological meat quality (Lefaucheur et al. 1991). Rodríguez-Sánchez et al. (2009) concluded that in Spanish natural-environment facilities, the seasonality of the growing-finishing period affects the carcass, and meat and fat quality of pigs. The summer pigs had a $13.2 \%$ thinner fat depth and a higher yield of shoulders and loins by $10.6 \%$ and $10.0 \%$, respectively than pigs fattened in the winter.

Many authors, inter alia Rosenvold \& Andersen (2003), Pugliese et al. (2003) and Lébret (2008) highlight the effect of maintenance conditions, in that animal management system, on animal growth rate and slaughter value of swine. Beattie et al. (2000) reported that pigs finished in enriched environments $\left(3.5 \mathrm{~m}^{2} / \mathrm{pig}\right.$, solid flooring with straw bedding) had greater growth rates during the last stage of finishing compared with pigs finished in a barren environment $\left(0.76 \mathrm{~m}^{2} / \mathrm{pig}\right.$, concrete slats). According to the Italian studies (Pugliese et al. 2003), the fatteners reared with access to outdoor-runs had the lowest dressing percentage but longer carcasses and a lower level of backfat as compared to the pigs finished under traditional indoor system Gentry et al. (2002) concluded that the swine rearing system did not affect on pig growth rate or meat quality traits, but it is clear that climatic conditions can play a significant role in welfare of pigs.

In conclusion, pig performance was assessed in vivo (fattening and slaughter value) and post mortem studies which showed a season to be a significant factor influencing a level of some haematological and biochemical indices. In winter period, fatteners' blood 
displayed increased leukocyte and immunoglobulin content with decreased red blood cell concentration. Whereas the animals finishing in the summer season had a higher growth rate. As compared to the winter period, the fatteners were found to have a higher content of crude protein, cholesterol and triglycerides as well as GGT, AST and cholinesterase concentration. In both seasons, the finishing pig carcasses had similar level of valuable cuts. A fattening season did not affect the technological value of the slaughter material obtained.

\section{References}

Beattie VE, O'Connell NE, Moss BW (2000) Influence of environmental enrichment on the behavior, performance and meat quality of domestic pigs. Livest Prod Sci 65, 71-79

Borell E von, Özpinar A, Eslinger KM, Schnitz AL, Zhao Y, Mitloehner FM (2007) Acute and prolonged effects of ammonia on hematological variables, stress responses, performance, and behavior of nursery pigs. J Swine Health Prod 15, 137-145

Dorman DC, Moulin FJM, McManus BE, Mahle KC, James RA, Struve MF (2002) Cytochrome oxidase inhibition induced by acute hydrogen sulfide inhalation: correlation with tissue sulfide concentrations in the rat brain, liver, lung, and nasal epithelium. Toxicol Sci 65, 18-25

Frank JW, Carroll JA, Allee GL, Zannelli ME (2003) The effects of thermal environment and spray-dried plasma on the acute-phase response of pigs challenged with lipopolysaccharide. J Anim Sci 81, 1166-1176

Gentry JG, McGlone JJ, Blanton JR Jr, Miller MF (2002) Alternative housing systems for pigs: influences on growth, composition, and pork quality. J Anim Sci 80, 1781-1790

Grellner GF, Fangman TJ, Carroll JA, Wiedmeyer CE (2002) Using serology in combination with acute phase proteins and cortisol to determine stress and immune function of early-weaned pigs. J Swine Health Prod $10,199-204$

Israël-Assayag E, Cormier Y (2002) Adaptation to organic dust exposure: a potential role of L-selectin shedding? Eur Respir J 19, 833-837

Lébret B, Massabie P, Granier R, Juin H, Mourot J, Chevillon P (2002) Influence of outdoor rearing and indoor temperature on growth performance, carcass, adipose tissue and muscle traits in pigs, and on the technological and eating quality of dry-cured hams. Meat Sci 62, 447-455

Lefaucheur L, Le Dividich J, Mourot J, Monin G, Ecolan P, Krauss D (1991) Influence of environmental temperature on growth, muscle and adipose tissue metabolism, and meat quality of swine. J Anim Sci 69, 2844-2854

Nehme B, Létournau V, Forster RJ, Veillette M, Duchaine C (2008) Culture-independent approach of the bacterial bioaerosol diversity in the standard swine confinement buildings, and assessment of the seasonal effect. Environ Microbiol 10, 665-675

Odink J, Smeets JFM, Visser IJR, Sandman H, Snijders JMA (1990) Hematological and clinicochemical profiles of healthy swine and swine with inflammatory processes. J Anim Sci 68, 163-170

Oliveira J, Yus E, Guitián FJ (2009) Effects of management, environmental and temporal factors on mortality and feed consumption in integrated swine fattening farms. Livest Sci 123, 221-229

Pugliese C, Madonia G, Chiofalo V, Margiotta S, Acciaioli A, Gandini G (2003) Comparison of the performances of Nero Siciliano pigs reared inddors and outdoors. 1. Growth and carcass composition. Meat Sci 65, 825831

Rodríguez-Sánchez JA, Ripoll G, Calvo S, Ariño L, Latorre MA (2009) The effect of seasonality of the growingfinishing period on carcass, meat and fat characteristics of heavy barrows and gilts. Meat Sci 83, 571-576

Rosenvold K, Andersen HJ (2003) Factors of significance for pork quality - a review. Meat Sci 64, 219-237

Sakai T, Nishino M, Hamakawa M, Yoon CS, Thirapatsakun T (1992) A note on the effects of environmental temperature on live-weight gain during fattening of pigs. Anim Prod 54, 147-149

Verheyen AJ, Maes GD, Mateusen B, Deprez P, Janssens G, de Lange G, Counotte G (2007) Serum biochemical reference values for gestating and lactating sows. Vet J 174, 92-98 
Wines BD, Hogarth PM (2006) lgA receptors in health and disease. Tissue Antigens 68, 103-114

Winnicka A (2008) [The reference values of basic laboratory research in veterinary medicine]. Publisher SGGW, Warsaw, Poland [in Polish]

Received 3 October 2011, accepted 23 April 2012.

Corresponding author:

Anna Chmielowiec-Korzeniowska

email: anna.korzeniowska@up.lublin.pl

Department of Animal Hygiene and Environment, Faculty of Biology and Animal Breeding, University of Life Sciences in Lublin, Akademicka 13, 20-950 Lublin, Poland 